\title{
Ovarian follicular growth during the oestrous cycle in two breeds of ewes of different ovulation rate, the D'Man and the Timahdite
}

\author{
A. Lahlou-Kassi and J. C. Mariana* \\ Institut Agronomique et Vétérinaire Hassan II, B.P. 6202 Agdal Rabat, Morocco, and \\ ${ }^{*}$ I.N.R.A. Reproductive Physiology, 37380 Nouzilly, France
}

\begin{abstract}
Summary. The population of growing follicles of diameter $>60 \mu \mathrm{m}$ was studied in 24 D'Man and 24 Timahdite ewes aged 2-2.5 years. The ovaries of each ewe were removed on Days 1, 2, 3, 4, 5, 7,9,11,13,15 or 17 of the oestrous cycle. Two ewes from each breed were ovariectomized. The mean ovulation rate was 2.9 in D'Man and 1.1 in Timahdite ewes and the mean numbers of normal follicles were 276 and 230 respectively. The distribution of the various sizes of follicles did not differ significantly between the two breeds. However, the number of follicles of diameter 118 to $462 \mu \mathrm{m}$ (follicles beginning to develop an antrum) and the number of follicles of diameter $>1285 \mu \mathrm{m}$ (large follicles possessing an antrum) were significantly greater in the D'Man than in the Timahdite ewes (136 and 106, and 7.1 and 4.5, respectively). The mean number of atretic follicles was similar for the two breeds (13.3 in the D'Man; 12.2 in the Timahdite), but in the D'Man there was a lower rate of atresia ( 54.9 compared with $66.7 \%$ ) for follicles of $1084-2141 \mu \mathrm{m}$ diameter. During the first days of the cycle there was a significant decrease in both breeds in the number of follicles of $60-118 \mu \mathrm{m}$ diameter. During this same period there was a significant decline in the number of follicles of diameter 119 to $462 \mu \mathrm{m}$ but in the D'Man ewes only. Therefore, the higher ovulation rate of the D'Man breed is due to the greater number of those follicles from which ovulatory follicles are recruited.
\end{abstract}

\section{Introduction}

The first studies on the relationship between the populations of primordial follicles and ovulation rate examined the relation between the number of germinal cells present in the ovary at birth in females from a given genetic line and the mean ovulation rate of that line (sheep: Land, 1970; Trounson, Chamley, Kennedy \& Tassell, 1974; Cahill, Mariana \& Mauléon, 1979; mouse : Jones \& Krohn, 1961 ; rat: Land, de Reviers, Thompson \& Mauléon, 1974). These authors all showed that there is a negative correlation between the number of primordial follicles and ovulation rate.

More recent studies have examined the relationship between other characteristics of the population of growing follicles and ovulation rate. Cahill et al. (1979) showed that the ovary of the Romanov ewe contains 1-5-2 times more growing follicles than does that of the Ile-de-France ewe which has an ovulation rate markedly less than that of the Romanov. The number of ovulations observed during an oestrous cycle is a function of two principal factors: (1) the number of ripening follicles at the moment of ovulation, which is modified by 3 characteristics of follicular dynamics, i.e. (i) the number of follicles starting to grow; (ii) the rate of growth of these follicles, (iii) the level of degeneration of follicles during their growth; and (2) the probability that a ripe follicle will ovulate. It is therefore reasonable to suppose that two breeds of ewe having very different ovulation rates would show clear differences in one or other or both of these principal factors. We therefore decided to study this in D'Man and Timahdite ewes, breeds characterized by an ovulation rate of 
$2.88 \pm 0.2$ and $1.09 \pm 0.03$ respectively (Lahlou-Kassi, 1980), and investigated: (1) the change in the number of growing follicles, normal or atretic, during the course of the oestrous cycle, and (2) the relationships between the various classes of growing follicles.

\section{Materials and Methods}

\section{Animals}

The experiment was carried out between January and November 1978 at the farm of the Hassan II Institute of Agriculture and Veterinary Science. Two lots of ewes, 24 D'Man and 24 Timahdite, were housed together, and received the same diet (green or dry cut forage plus concentrates). The ewes were all primiparous and were 2-2.5 years old at the start of the experiment (January 1978).

\section{Experimental design}

Between January and the start of September 1978, the ewes were placed with a vasectomized ram each day for $1 \mathrm{~h}$ in the morning and $1 \mathrm{~h}$ in the afternoon to confirm that all ewes showed normal oestrous behaviour and regular oestrous cycles.

From the beginning of September, the period during which the two breeds were still in their sexual season, oestrus was synchronized. All ewes received a subcutaneous implant of $375 \mathrm{mg}$ progesterone (Silestrus: Abbot Laboratories, Hellas S.A., Athens, Greece) which was withdrawn 14 days later. To overcome any interference of this synchronization on folliculogenesis, ovariectomy was performed during the second cycle after withdrawal of the implants.

Before ovariectomy, ewes of each breed were allocated in pairs to various days of the cycle at random at the start of the experiment. Bilateral ovariectomy was performed on Days 1, 2, 3, 4, 5, 6, $7,9,11,13,15$ or 17 after oestrus was observed. Ovariectomy was performed under general anaesthesia with thiopentone sodium (T. N. Nesdonal: Specia Laboratories, Paris, France) using paramedial abdominal laparotomy.

\section{Treatment and analysis of ovaries}

Immediately after removal, the two ovaries of each ewe were fixed in Bouin-Hollande fluid, and the numbers of corpora lutea on each were counted to provide mean values of 2.92 and 1.09 ovulations per ewe for the D'Man and Timahdite breeds respectively. These results are similar to those already published for the two breeds (Lahlou-Kassi, 1980). After embedding in paraffin wax, the ovaries were cut into serial sections of $5 \mu \mathrm{m}$ thickness, and one section in every 5 was mounted on a microscope slide and stained with Regaud's haematoxylin.

Taking into account the thickness and the frequency of the sections and the mean size of the oocyte (Brand \& de Jong, 1973; Cahill et al., 1979) each oocyte would have been present in at least one of these sections and most oocytes in two sections. The oocyte was therefore used as a marker to avoid counting the same follicle twice. All follicles with 2 layers of follicular cells enclosing the oocyte were counted. It was also ascertained whether there was an antrum or whether the follicle was atretic (see below).

In those sections containing an oocyte, the surface area of each section was measured using an ASM Leitz Planimeter. It was assumed that the surface area thus calculated would represent follicular size, since the oocyte was generally in a central position. However, very large follicles had sometimes either burst or folded, making an exact measurement of their surface area very difficult.

\section{Classification of follicles}

Dimensions. Follicles with 2 layers of granulosa cells and a diameter of $>60 \mu \mathrm{m}$ were considered to be growing follicles. These follicles were placed according to their surface area into 26 classes, the 
upper limits of which were a geometric progression by a factor of 1.41 . We adopted a logarithmic classification based on the supposition that follicular growth is largely exponential. A second stage of this analysis was to regroup the 26 size classes into 4 larger groups based on morphological criteria relating to follicular development, such as formation of an antrum and atresia.

Qualitative aspects. A follicle was considered normal if there were fewer than 10 pycnotic cells in the peripheral granulosa or in the cumulus oophorus. Otherwise, the follicle was considered to be atretic. Follicles showing very advanced stages of atresia with disintegration of the granulosa cells were not included in our calculations. Such follicles are not contemporaries of other normal follicles for any given class, and we have no means of estimating the timing of the start of atresia. Therefore, taking account of such follicles would bias our analysis of cyclic events. In any case, such follicles never represented more than $3 \%$ of the total number of follicles present in the ovary.

Statistical analysis. The comparison of the distribution of follicles according to the size classes in the two breeds was carried out using the non-parametric test of Kolmogorov-Smirnov (Conover, 1980). The comparison of the number of follicles in the four groups during the course of a cycle was made using the Kruskal-Wallis non-parametric analysis of variance. The correlations between the numbers of follicles in successive classes were calculated using a correlogram (Chatfield, 1975). The values of the correlations between two classes where they were separated by greater than 14 classes were not taken into account since their calculation was based on very few data and so had very little meaning.

\section{Results}

Since the study consisted of two parts, the results are presented as (1) the overall picture of the follicular populations in cyclic ewes in each of the two breeds and (2) the evolution of this follicular population during the course of an oestrous cycle.

\section{Distribution of follicles in the cyclic ewe}

Normal follicles. The mean number of normal growing follicles in the two ovaries during the course of a cycle was $276 \pm 52$ in the D'Man and $230 \pm 45$ in the Timahdite ewes $(P>0.05)$. The distribution of follicles according to size in the two breeds (Text-fig. 1) can be characterized as follicles ranging in diameter from 60 to $100 \mu \mathrm{m}$, from 101 to $913 \mu \mathrm{m}$ and those from 914 to $3568 \mu \mathrm{m}$ and more. There were no significant differences between the two breeds in the two distributions although the slight superiority of the D'Man in terms of total number of growing follicles was also present in 22 of the 26 classes.

Significant correlations were found between the number of follicles in 11 successive classes $(P$ $<0.05$ ) (Text-fig. 2). For example, the number of follicles in class 3 was positively correlated with the number of follicles in each of the following 11 classes. The magnitude of these correlations did not differ between the two breeds.

The percentage of follicles in each of the classes showing an antrum was similar for the two breeds up to class 6 but thereafter the difference increased with increasing size (Text-fig. 3 ): $50 \%$ of follicles with an antrum occurred in class 9.5 for the Timahdite ewes and in class 11 for the D'Man ewes. All the follicles in the Timahdite ewes possessed an antrum by class 12 , but it was not until class 13 that this was true for the D'Man.

Atretic follicles. Atretic follicles first appeared during class 13 in the two breeds. The total mean number of atretic follicles per ovary was $13.3 \pm 3$ in the D'Man and $12.2 \pm 3.2$ in the Timahdite ewes. The mean level of atresia pooled over all classes between classes 13 and 26 , was $33 \%$ in the D'Man and $36 \%$ in the Timahdite ewes. The course of atresia was similar in the two breeds: a 


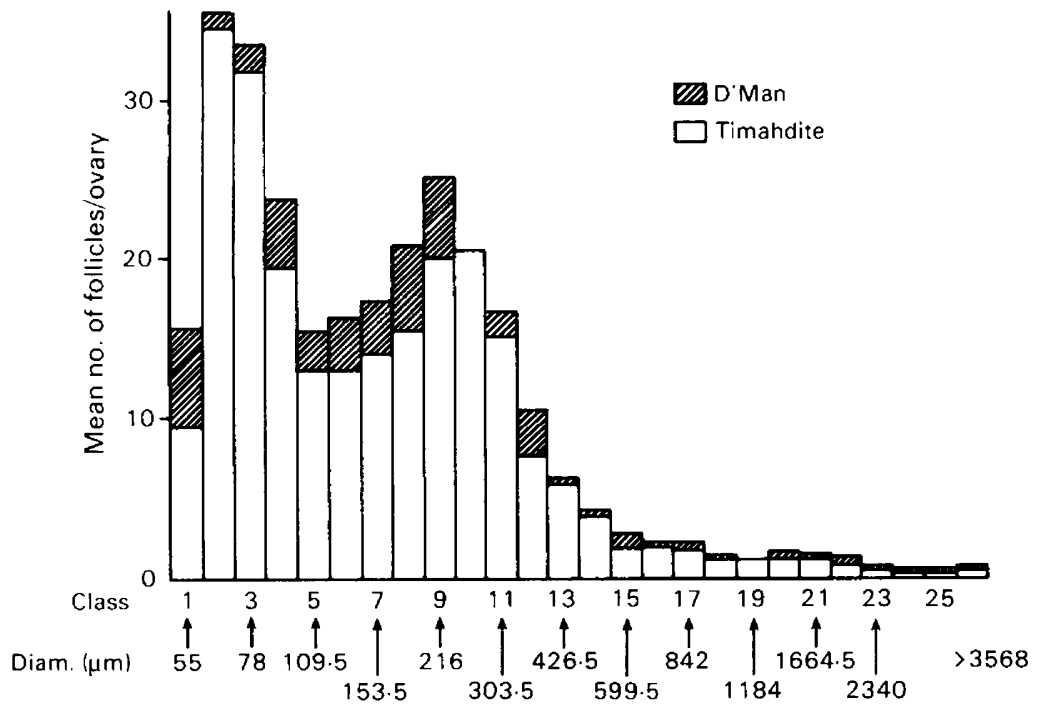

Text-fig. 1. Distribution of normal follicles in the ovaries of D'Man and Timahdite ewes as a function of class and size.

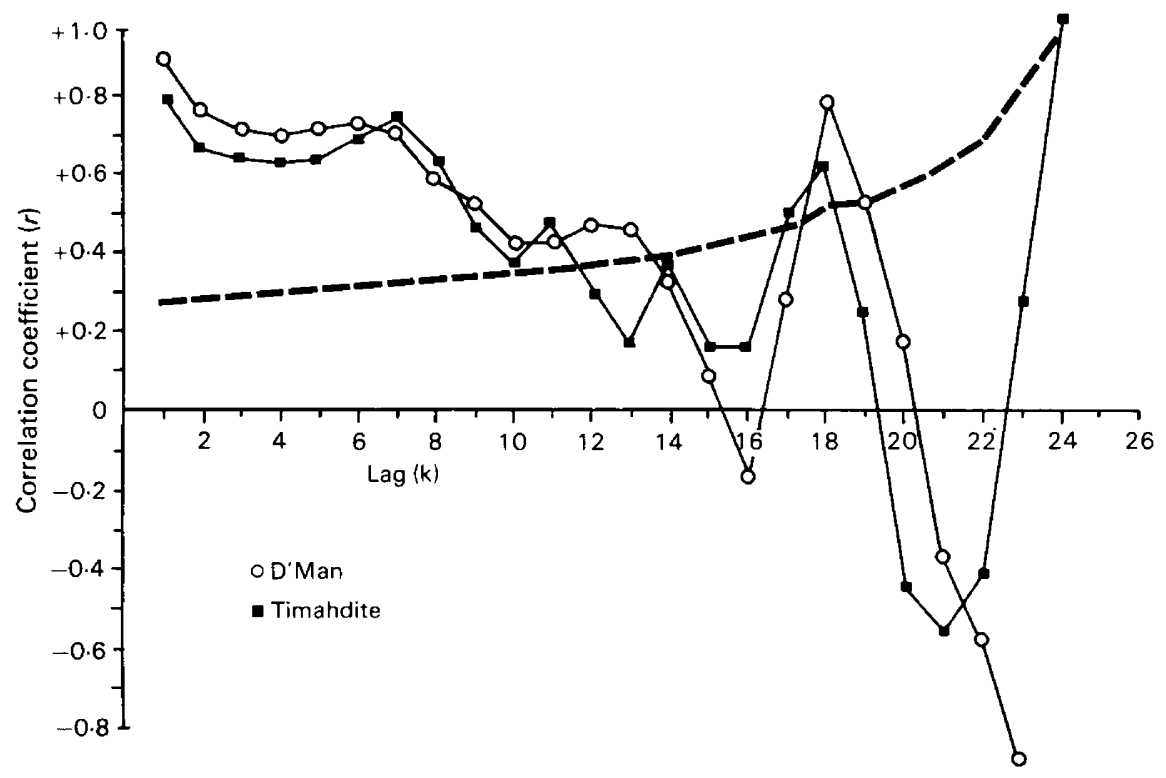

Text-fig. 2. Values of the correlation coefficient of the number of follicles between two classes separated by lag $(\mathrm{k})$ where $\mathrm{k}$ is the interval between classes. The broken line gives the limit of significance.

steady increase in follicles of diameter $>391 \mu \mathrm{m}$, a plateau in follicles of diameter $>1084 \mu \mathrm{m}$ and a decrease in follicles of diameter $>2826 \mu \mathrm{m}$ (Text-fig. 4).

D'Man ewes were characterized by a maximum rate of atresia $(54.9 \%)$ which was significantly $(P<0.05)$ lower than that of the Timahdite $(66.7 \%)$ for follicles of 1084 to $2141 \mu \mathrm{m}$ diameter. 


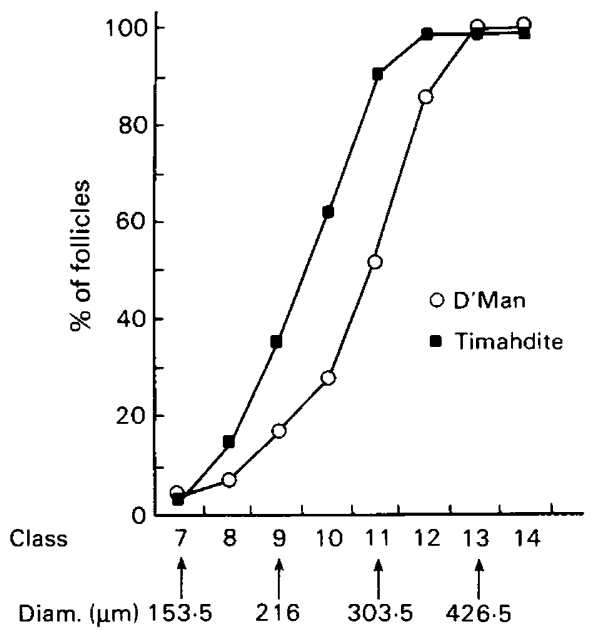

Text-fig. 3. Percentage of normal follicles showing an antrum as a function of class and size in D'Man and Timahdite ewes.

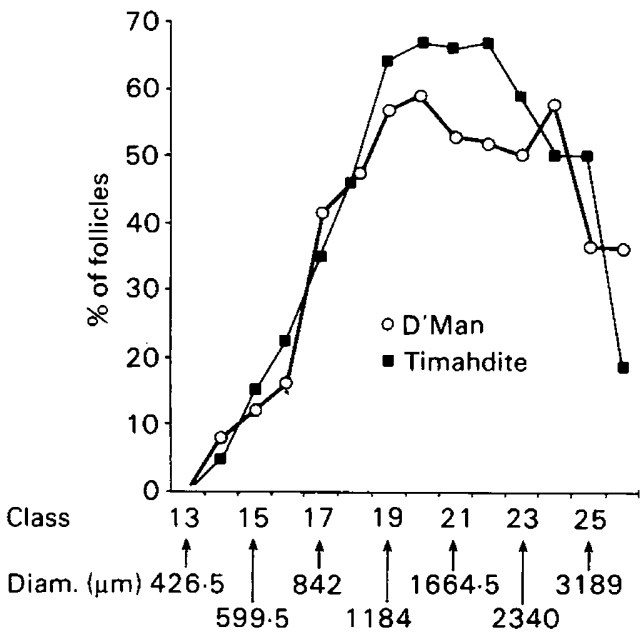

Text-fig. 4. Percentage of follicles showing atresia as a function of class and size in D'Man and Timahdite ewes.

Definition of the four groups of follicular growth

The system of classification that we have so far used can be considered a working system, allowing us to reclassify follicles according to their size. We subsequently defined 4 groups of follicles on the basis of the 3 components of growth that we have just defined.

Group I. Follicles of $60-118 \mu \mathrm{m}$ diameter and which have started to grow.

Group II. The critical phase in follicular growth when the antrum is formed and follicular diameter is $119-462 \mu \mathrm{m}$. 
Group III. During which the chance of atresia increases with increasing size and follicular diameter is $463-1184 \mu \mathrm{m}$.

Group $I V$. Follicles of diameter $\geqslant 1185 \mu \mathrm{m}$ which constitutes a reserve of follicles destined to ovulate.

For Groups I, II, III and IV respectively, the mean numbers of follicles were $100 \pm 27,106 \pm$ $15 \cdot 7 ; 12 \pm 3.8$ and $4.5 \pm 1.8$ for the Timahdite ewes and $106 \pm 27 \cdot 3 ; 136 \pm 22.7 ; 14 \pm 2.8$ and $7 \cdot 1 \pm 1.6$ for the D'Man ewes. The numbers of follicles in Groups II and IV were significantly $(P<0 \cdot 05)$ higher in the D'Man than in the Timahdite ewes.

Changes in the follicular population during the course of the oestrous cycle

Normal follicles. For Group I, the range of variation in the number of normal follicles was 47 to 180 in the Timahdite and 70 to 225 in the D'Man ewes (Text-fig. 5). In the Timahdite ewes, the number of follicles significantly decreased with day of cycle $(P<0.05)$. Based on the regression of the number of follicles on day of cycle, it was calculated that during the first 3 days of the cycle, there was a mean decrease of 24.3 follicles per day, while over the whole cycle there was a mean decrease of 8.75 follicles per day. In the D'Man ewes, the number of follicles significantly decreased all through the cycle $(P<0.05)$, and this decrease was greatest during the first 5 days, with a mean of 30 follicles per day on Day 3 of the cycle. As for the Timahdite ewes, this rate decreased as the cycle progressed, the overall mean rate per day being 7 (Text-fig. 5).

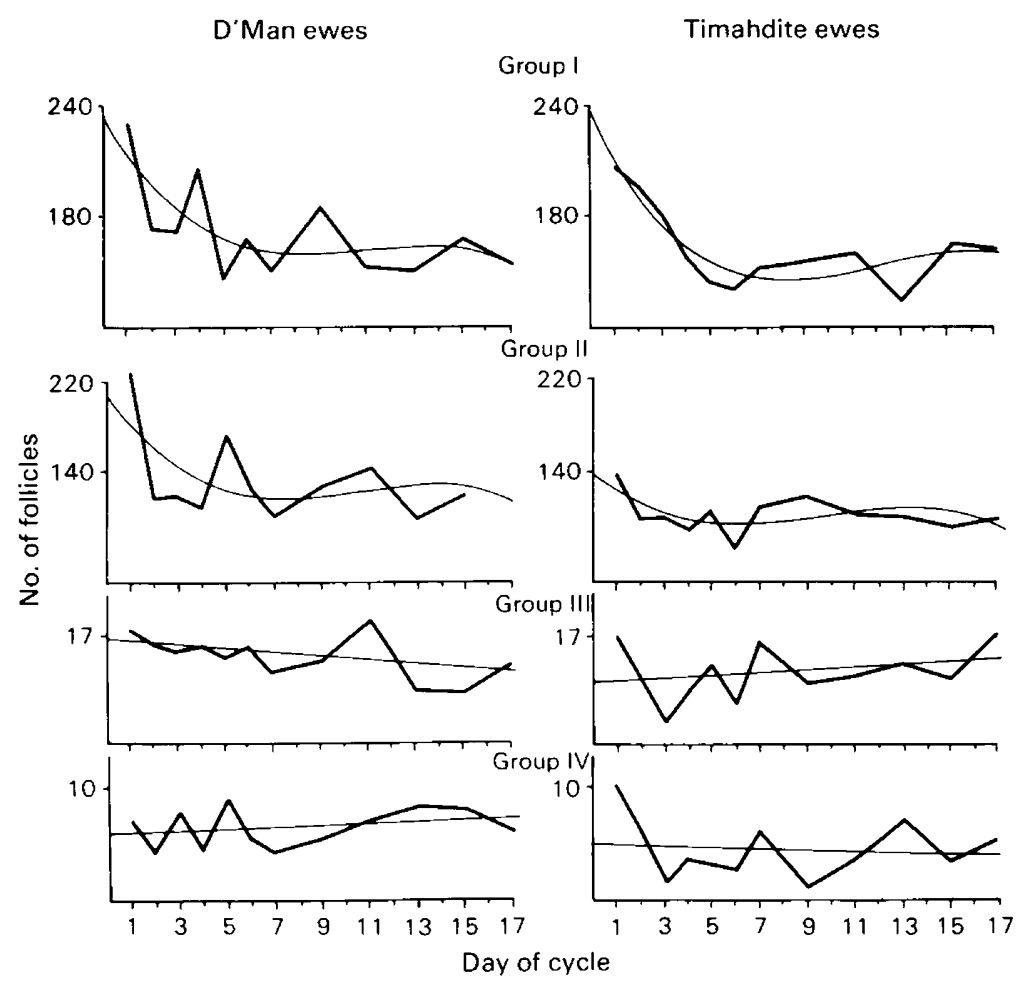

Text-fig. 5. Mean number of follicles present in Groups I (60-118 $\mu \mathrm{m})$, II (119-462 $\mu \mathrm{m})$, III $(463-1184 \mu \mathrm{m})$ and IV $(>1184 \mu \mathrm{m})$ during the oestrous cycle in D'Man and Timahdite ewes. The broken lines indicate the regression of follicle number on day of cycle. 
The mean number of follicles in Group II during the oestrous cycle varied from 71 to 177 in the Timahdite and from 96 to 225 in the D'Man ewes. In the Timahdite ewes, the number of follicles in Group II was relatively constant over the whole cycle, with a very slight decrease during the first 6 days (Text-fig. 5). In contrast, the number of Group II follicles in the D'Man ewes was significantly $(P<0.05)$ elevated during Days $1-5$ of the cycle compared with the remaining days, and there was a significant regression of the number of follicles as a function of day of cycle (Text-fig. 5). Over all days of the cycle, the mean decrease in the number of follicles of this group was 8.75 per day. The population of follicles of Group III was relatively stable in the two breeds (Text-fig. 5) varying from 4 to 17 in the Timahdite and 8 to 17 in the D'Man ewes. There was no influence of the day of cycle on the number of Group III follicles.

The mean number of Group IV follicles varied from 1.5 to 10 in the Timahdite and from 4 to 9 in the D'Man ewes. There was no significant effect of day of cycle on follicle number.

Since these classes could have contained follicles whose size exceeded $4000 \mu \mathrm{m}$, we examined the changes in size of the biggest follicles. During the course of the oestrous cycle, we observed no significant difference in the size of the biggest follicle, and no significant difference between the two breeds in the size of the biggest follicle. The mean standard deviation per ewe in the size of the 3 biggest follicles was slightly greater in the Timahdite than in the D'Man ewes but this difference was not signifcant.

Atretic follicles. The rate of atresia of Group III and IV follicles was very stable during the course of the cycle in the D'Man ewes, while it fluctuated widely in the Timahdite ewes. However, there was no effect of day of cycle on atresia of these follicles. There were differences between the two breeds in the rate of atresia of Group IV follicles, being higher in the Timahdite than in the D'Man ewes all through the cycle $(P<0.05)$.

In the D'Man ewes, in which there was variation among animals in ovulation rate, we found a significant correlation between ovulation rate of the preceding cycle and the number of Group IV follicles $(r=0.44, P<0.05)$. In contrast, ovulation rate was not significantly correlated with the number of follicles in Groups I, II and III or with the number of atretic follicles in Groups III or IV.

\section{Discussion}

The first important result of this study is the similarity found between the two breeds in the distributions of the various classes of growing follicles, of the correlograms of the various classes of growing follicles and in the rate of atresia. Such results agree with those reported by Brand \& de Jong (1973), Turnbull, Braden \& Mattner (1977) and Cahill et al. (1979) on other breeds of sheep of widely varied ovulation rate. Furthermore, the structure of the population of growing follicles and the magnitude of the correlations found by the above authors are very similar to those found in our study. These striking resemblances suggest that the dynamics and the renewal of growing follicles are regulated by the same type of law irrespective of breed or ovulation rate; i.e. by some sort of intra-ovarian equilibrium (see review by Mariana, 1980). However, if the regulation of follicular dynamics is the same in all breeds, ovulation rate must be controlled by the level of regulation, but how does this difference operate in the two breeds?

Firstly, there were significantly more preantral, early antral and preovulatory follicles in the D'Man than in the Timahdite ewes. Furthermore, in the D'Man ewes there was a significant correlation between ovulation rate and the number of preovulatory (Group IV) follicles. Such a result has previously been reported by Cahill et al. (1979) for two breeds of different ovulation rates, the Romanov and the Ile-de-France. Cahill et al. (1979) also showed a significant deviation between the two breeds in the number of growing follicles. This result explains the observations of Bindon, Ch'ang \& Turner (1971), Smith (1976) and A. Lahlou-Kassi \& J. C. Mariana (unpublished data) concerning the positive correlation between the prolificacy of a breed of ewe and its response 
in terms of numbers of ovulations to PMSG. Monniaux, Chupin \& Saumande (1983) showed a positive correlation between the number of growing follicles in the ovary at the time of treatment and the number of luteinized follicles and the number of ovulations induced by an injection of 1200 i.u. PMSG on Day 12 of the oestrous cycle in the cow.

The second factor in this regulation appears to be the level of atresia. Preovulatory follicles, i.e. those of $1 \cdot 3-2 \cdot 1 \mathrm{~mm}$ diameter, have a lower chance of becoming atretic in the D'Man than in the Timahdite ewes. The probability of degeneration of these follicles is about 1 in 2 in the D'Man and 2 in 3 in the Timahdite ewes. This clear difference further contributes to the difference in the numbers of normal preovulatory follicles in the two breeds. We have been able to show this through an appropriate reclassification of follicles which, in our opinion, explains why Cahill et al. (1979) found no difference in the rate of atresia between Romanov and Ile-de-France ewes.

Another distinctive difference in our breeds was the appearance of the antrum at a later stage of follicular development in the D'Man than in the Timahdite ewes. This would suggest that the multiplication of granulosa cells is more active in the former. This is further supported by the result of Turnbull, Land \& Scarramuzzi (1978) who, in effect, stated that the rate of growth of small follicles was faster in ewes of higher ovulation rate (Booroola, Finnish Landrace) than in ewes of low ovulation rate (Merinos). These three features allow us to understand why there are more Group IV follicles in ewe breeds of high ovulation rate.

The presence of normal follicles at various stages of development and of atretic follicles throughout the whole oestrous cycle is in agreement with the findings of Hutchinson \& Robertson (1966), Brand \& de Jong (1973) and Turnbull et al. (1977) for the ewe and of Rajakoski (1960) and Mariana \& Nghuyen Huy (1973) for the cow. This growth of follicles, which can be considered as 'tonic' appears to be a continuous phenomenon, as opposed to ovulation which is cyclic; such a continuity is seen also in the non-pubertal female lamb (Land, 1970; A. Lahlou-Kassi \& J. C. Mariana, unpublished data), in the easonally anoestrous ewe (Cahill et al., 1979) and in the pregnant ewe (Smeaton \& Robertson, 1971).

The fact that there are more Group II and Group IV follicles all through the cycle in D'Man than in Timahdite ewes indicates that the D'Man ewe is continually able to produce several ovulations. This would explain why we have been able to induce ovulation using prostaglandins in three groups of D'Man ewes injected on Days 6, 9 or 11 of the oestrous cycle (A. Lahlou-Kassi, unpublished data); the ovulation rate was similar in the three groups and to that of untreated ewes.

The number of Group I follicles was 1.5-2.0 times greater on the day after oestrus (i.e. Day 1) than on other days of the cycle: it decreased significantly over the next 3 or 4 days before stabilizing. This means that there was a spurt of growth of follicles of diameter $\leqslant 60 \mu \mathrm{m}$ towards classes of greater size. This probably takes place around oestrus, since the number of follicles in Groups I and II on the day before oestrus were much lower than those seen on the day after oestrus. A similar phenomenon has been observed for the mouse by Pedersen (1970) who noted that the number of follicles starting their growth was much greater around oestrus than on other days of the cycle. However, this was only seen in Group I follicles in the Timahdite ewes and the number of Group II follicles did not vary signficantly over the cycle. This may mean that the number of follicles which start to grow at around oestrus is much greater in the D'Man than in the Timahdite ewes. The number of large follicles was very constant all through the cycle. As a consequence, the number of follicles per day entering those classes whose size ranged from 462 to $1184 \mu \mathrm{m}$ (Group III) and $\geqslant 1184 \mu \mathrm{m}$ (Group IV) is equal to the number which leave these classes, either by growth or by atresia. Thus the number is stable no matter what the stage of the cycle.

The appearance of one or two large follicles (diameter $\geqslant 2.5 \mathrm{~mm}$ ) on Days 3-4 and 9-10 of the cycle is similar to results reported by Hutchinson \& Robertson (1966), Smeaton \& Robertson (1971), Brand \& de Jong (1973) and Turnbull et al. (1977) for the ewe, and by Rajakoski (1960) and Choudary, Gier \& Marion (1968) for the cow. These authors all concluded, with the exception of Turnbull et al. (1977), the existence of 1-4 waves of follicular growth, the end-point of each wave being the appearance of a large follicle. However, we agree with Turnbull et al. (1977) that the wave 
theory is not satisfactory for the following reasons. (1) On each day of the cycle, normal and atretic follicles of various sizes are present, indicating a continual growth and regression of follicles. (2) The appearance of follicles of very large diameter during the luteal phase of the cycle does not happen in all ewes or at precisely determined phases of the cycle. (3) The growth of a follicle to the ovulatory stage may be stimulated at any time during the oestrous cycle simply by modifying the hormonal environment by suppression of the corpus luteum (Smeaton \& Robertson, 1971; A. Lahlou-Kassi, unpublished data).

We therefore suggest that follicular growth is continuous and that, when the hormonal environment allows, through inhibition or stimulation, one or more of the large non-atretic follicles continues to grow to attain ovulatory size. This final phase requires only a short time (about $48 \mathrm{~h}$ ), because on the day before oestrus the largest follicle that we observed was only $4 \mathrm{~mm}$ in diameter. This is similar to the observations reported by Smeaton \& Robertson (1971).

The higher ovulation rate of the D'Man ewes may be explained by a greater number of follicles in that size class from which ovulatory follicles are recruited. This is probably induced by FSH stimulation which is greater in the D'Man than in the Timahdite ewes (Lahlou-Kassi, Schams \& Glatzel, 1983). It is also possible that a certain selection may exist among follicles at the end of the cycle in the D'Man ewe. This would ensure homogeneity amongst these follicles as regards their receptivity to pituitary signals during the period immediately before ovulation (Goodman \& Hodgen, 1983).

We thank Mr R.J. Kilgour for assistance in the English translation of the manuscript and also the Staff of INAV for management of the experimental animals.

\section{References}

Bindon, B.M., Ch'ang, T.S. \& Turner, H.N. (1971) Ovarian response to gonadotrophin by Merino ewes selected for fecundity. Aust. J. agric. Res. 22, 809820 .

Brand, A. \& de Jong, W.H.R. (1973) Qualitative and quantitative micromorphological investigations of the tertiary follicle population during the oestrous cycle in sheep. J. Reprod. Fert. 33, 431-439.

Cahill, L.P., Mariana, J.C. \& Mauléon, P. (1979) Total follicular population in ewes of high and low ovulation rates. J. Reprod. Fert. 55, 27-36.

Chatfield, C. (1975) Interpreting the correlogram. In The Analysis of Time Series, Theory and Practice, pp. 2530. Eds M. S. Bartlett \& D. Cox. Chapman \& Hall Ltd, London.

Choudary, J.B., Gier, H.T. \& Marion, G.B. (1968) Cyclic changes in bovine follicles. J. Anim. Sci. 27, 468471.

Conover, W.J. (1980) Statistics of the KolmogorovSmirnov type. In Practical Non-Parametric Statistics, 2nd edn, pp. 344-393. Wiley \& Sons, New-York.

Goodman, A.L. \& Hodgen, G.D. (1983) The ovarian triad of the primate menstrual cycle. Recent Prog. Horm. Res. 39, 1-73.

Hutchinson, J.S.M. \& Robertson, H.A. (1966) The growth of the follicle and corpus luteum in the ovary of the sheep. Res. vet. Sci. 9, 307-311.

Jones, E.C. \& Krohn, P.L. (1961) The relationships between age, numbers of oocytes and fertility in virgin and multiparous mice. J. Endocr. 21, 469-495.

Lahlou-Kassi, A. (1980) Seasonal variation in oestrus and ovarian activity of two Moroccan sheep breeds:
D'Man and Timahdite. Proc. 9th Int. Congr. Anim. Reprod. A.I., Madrid, Symposium n. 1. pp. 186189.

Lahlou-Kassi, A., Schams, D. \& Glatzel, P. (1983) Plasma gonadotrophin concentrations during the oestrous cycle and after ovariectomy in two breeds of sheep with low and high fecundity. J. Reprod. Fert. 70, 165173.

Land, R.B. (1970) A relationship between the duration of oestrus, ovulation rate and litter size of sheep. $J$. Reprod. Fert. 23, 49-53.

Land, R.B., de Reviers, M.M., Thompson, R. \& Mauléon, P. (1974) Quantitative physiological studies of genetic variation in the ovarian activity of the rat. $J$. Reprod. Fert. 38, 29-39.

Mariana, J.C. (1980) Some remarks on the long term trends and some short regulations in the follicular growth. Proc. 9th Int. Congr. Anim. Reprod. A.I., Madrid 79-99.

Mariana, J.C. \& Nghuyen Huy, N. (1973) Folliculogenese chez la vache. Annls Biol. anim. Biochim. Biophys. 13, 211-221.

Monniaux, D., Chupin, D. \& Saumande, J. (1983) Superovulation responses of cattle. Theriogenology 19, 55-81.

Pedersen, T. (1970) Follicle kinetics in the ovary of the cyclic mouse. Acta endocr. Copenh. 64, 304-323.

Rajakoski, E. (1960) The ovarian follicular system in sexually mature heifers with special reference to seasonal, cyclical and left-right variations. Acta endocr., Copenh., Suppl. 34, 1-68. 
Smeaton, T.C. \& Robertson, H.A. (1971) Studies on the growth and atresia of Graafian follicles in the ovary of the sheep. J. Reprod. Fert. 25, 243-252.

Smith, J.F. (1976) Selection for fertility and response to PMSG in Romney ewes. Proc. N.Z. Soc. Anim. Prod. 36, 247-251.

Trounson, A.O., Chamley, W.A., Kennedy, J.P. \& Tassell, R. (1974) Primordial follicle numbers in ovaries and levels of $\mathrm{LH}, \mathrm{FSH}$ in pituitaries and plasma of lambs selected for and against multiple births. Aust. J. biol. Sci. 27, 293-299.
Turnbull, K.E., Braden, A.W.H. \& Mattner, P.E. (1977) The pattern of follicular growth and atresia in the ovine ovary. Aust. J. biol. Sci. 30, 229-241.

Turnbull, K.E., Land, R.B. \& Scarramuzzi, R.J. (1978) Patterns of growth of Graafian follicles in sheep and their relationship to ovulation rate. Theriogenology 8 , 172.

Received 13 December 1983 